\title{
10 Aladura Churches as agents of social transformation in South-West Nigeria
}

\author{
Akinwumi Akindolie
}

\section{Introduction}

Religious organisations are one of the workable factors that make lives meaningful through their social transformative activities, which change people and communities in general. Corroborating Nabofa's theory of religion $(1988,54)$, Scharf remarks that religion always permeates, mediates and pervades the lives of persons, relationships, institutions, processes and structures which by implication serve as social functions $(1970,21)$. Religion is not all about spirituality, it is also a social phenomenon (Akindolie 2012,6). Apart from spiritual experience inherent in religious practices and beliefs, there are lots of physical manifestations of religious events that transform the social life of people. This is supported by the functionalist perspective, which considers religion to be needed by society to function well (Haralambos and Holborn 2008, 396). This is contrary to some western social thinkers who stress that religion is a mere illusion and that the phenomenon will disappear or become progressively attenuated when there is an expansion in modern globalisation (Borowik 2002, 239-252). However, religion has disappeared nowhere but transformed everywhere (Akindolie 2012, 6).

Several scholars, for example Oyewole (2004, 21), Akindolie $(2012,1)$, Tachin (2019, 393), Familusi (2010, 158-160), Familusi and Oke (2011, 90-91) and Johnstone (2001, 181-182) among others, have written extensively on religion as a tool for social transformation. However, the literature has concentrated on the social contributions of Mission Churches and Pentecostal Churches and their social transformation activities, while little attention has been paid to African Initiated Churches. 'While it has been acknowledged that many [African Initiated Churches] provide coping mechanisms in adverse environments, support in social transformation and social capital, little information is available on their role as development actors' (Öhlmann et al. 2016, 1). In line with this, there is a need to look at the social contributions of Aladura Churches in South-West Nigeria, a West African expression of African Initiated Christianity. Hence this chapter traces how Aladura Churches' social activities help to transform the people and communities around them. In addition to existing literature, the chapter relies on interview material from the 
Nigeria field study of the Research Programme on Religious Communities and Sustainable Development headed by Marie-Luise Frost in the framework of the research project 'Potentials of Cooperation with African Initiated Churches for Sustainable Development'. ${ }^{1}$

\section{The social transformational role of religion in Nigeria}

Writing on the subject of education as a means of transformation, Oyewole stresses that there is no gainsaying about the fact that the coming of Christianity and Islam to African countries brought about transformation in their educational systems. He affirms that before the advent of the white Europeans and Arabs to African countries the system of education was an informal one. According to Oyewole, Nigerians exposed to western education developed a sense of transformation, thereby leading to improved educational standards of the African leaders and members of the entire society (Oyewole 2004, 21).

In addition, Ositelu describes missionaries' contribution as a factor in the growth of national consciousness through the establishment of newspapers. One example is the newspaper Iwe Iroyin founded by an Anglican missionary in Nigeria, Henry Townsend of the Church Missionaries' Society (CMS), in 1859 (Ositelu 2010, 106). Moreover, Europeans missionaries contributed to the linguistic unification of African languages. According to Adeoba (2012, 57), missionaries did not only spread the use of English as a lingua franca, but also standardised Nigerian languages through the translation of the Holy Bible. Local dialects were unified into common language for several ethnic groups. This standardisation of languages promoted the functioning of administration, politics and commercial activities (Adeoba 2012, 48-49).

Oyewole furthermore observes that Islamic education served as a tool for educational change by the teaching of converts to read the Holy Quran - the sacred text of Islam. Today, there are many primary and secondary schools as well as colleges that were established by Islamic missionaries (Oyewole 2004, 21).

Bourdillon further investigates the spiritual level of health where he stated that religious organisations have contributed greatly to the improvement of people's health. In this situation, Independent and Pentecostal Churches and some Islamic organisations, especially those advocating prophetic healing, are easily accessible and often render free healing services based largely on spiritual means faith, prayer and fasting. They also use consecrated water, olive oil and the support of the believing community in their healing services (Bourdillon 1991, 146). This has been attested to by many beneficiaries of these spiritual healings otherwise known as cura divina (divine healing) which constitute a reality in the African experience (Ayegboyin and Ishola 1997, 29).

Familusi opines that religion has a strong influence on politics in various aspects such as style of governance, policy formation and electoral processes. Again, he admits that religious ethical teaching influences the adherents positively and such impact thus provides good leadership and obedient followership. 
In relation to this, Familusi points out that religion as an agent of social control helps to keep people within the norm of the society, which is the real basis of politics. Thus, religion as an agent of transformation prepares the mind of man to be a good politician and citizen who will always fall back upon his religion to guide him in his social activities (Familusi 2010, 158-160).

Similarly, Dzurgba submits that religion has a pervading and powerful influence on political institution and process. He asserts that it is an agent of political socialisation, directly or indirectly. He establishes that religion has a significant influence on party affiliation, campaign hustling, voting behaviour and pressure group formation. In his words, the religious influence that brings about change in these aforementioned political exercises may be overt or covert, depending on the nature of such a political process (Dzurgba 1991, 54). He asserts that in a dominant Christian community, campaign hustling may give emphasis to Christian' interests such as the return of schools established by missionaries to churches, a better policy on pilgrimage to Israel and favourable government policy on Christian hospitals and clinics.

Corroborating these claims in a pluralistic society like Nigeria, Dzurgba puts forward that any political party that wants to succeed must take into consideration the involvement of different religious adherents, notably Christians and Muslims. For instance, in the 2011 Nigerian elections, a majority of the political parties' leaders were either from Christian or Muslim communities. However, in a system like this, people get assurance from the party for which they will vote for to represent their interests at local, state and national levels. Thus, Dzurgba $(1991,54)$ states that politicians rarely ignore or make mistakes about religion during campaign hustling; it is at this time that some politicians become born again. Voting behaviour is transformed by the religious faith of voters and by implication a religious consideration plays an important part in a voter's decision as to whom to vote for in a particular election. Furthermore, he adds that political pressure groups might be formed on the basis of the various religious institutions of Christianity, Islam and African traditional religion.

Dzurgba is also of the opinion that religious thought and behaviour inspire honesty in business as it is said that 'honesty is the best policy'. It does not allow traders to be associated with fraudsters. By implication, religion helps good reputation and this in turn paves the way for societal transformation. Similarly, Johnstone (2001, 181-182) states that, along with honesty, dedication and commitment, religious faith inspires initiative, diligence and efficiency of labour. All these bring about increased productivity in business. With work ethics, business could flourish well, hence, the transformational role of religion in the economy. In conclusion, from the literature reviewed above, we know that scholars expatiated on religion and transformation from different perspectives, but no adequate works have been done on the contribution of Aladura Churches and their social transformation activities.

On Mission and Pentecostal Churches' current contributions towards social transformation in Nigeria, Familusi and Oke, for example, discuss Christian organisations' engagement in poverty alleviation. According to them, the Catholic 
Church for instance, through the Justice Development and Peace Commission (JDPC), has multifarious poverty reduction mechanisms in various Nigerian dioceses. Members and non-members alike benefit from vocational training, microcredit schemes and charity offered by the church. Associated with this, the Owerri Archdiocese, for example, runs a massive farm with animal husbandry and crop production on over 80 hectares of land irrigated with water from the Onumurukwa River (Familusi and Oke 2011, 90). Furthermore, the Methodist Church in Nigeria under the auspices of the United Methodist Committee on Relief inter alia contributes to poverty alleviation through agricultural activities, microcredit schemes and microenterprise development (Familusi and Oke 2011, 91). The Anglican Church has been equally proactive in poverty alleviation, as has the Baptist Church (Nigerian Baptist Convention 2009, 6-11). With respect to Pentecostal Churches, Oguntoyinbo-Atere provides an exhaustive description of the Redeemed Christian Church of God's programmes for the poor in Lagos. Among other things, the church engages in a God's provision programme, which takes care of the old and the handicapped, single mothers, the jobless, helpless orphans and the sick. The Christian Association of Nigeria (CAN), according to Atere, makes a difference in feeding prison inmates and the destitute, and runs a scholarship scheme for poor students (Oguntoyinbo-Atere 2005, 188-197). Akindolie (2012) has described the social work of the Chapel of Resurrection, a joint Methodist and Anglican campus congregation at the University of Ibadan. This church implements social transformation programmes for indigent people. Widows, widowers, students and others who solicit financial and other assistance are being taken care of. Apart from welfare, the church organises a 'Resurrection Youth Education Centre' for extramural classes for candidates preparing for various examinations (Akindolie 2012, 68).

From the above, we appreciate the contributions of Familusi and Oke (2011), Oguntoyinbo-Atere (2005) and Akindolie (2012) among others towards Mission and Pentecostal Churches' social transformation programmes. This chapter intends to complement the existing literature by providing a case study focusing on Aladura Churches in South-West Nigeria.

\section{Aladura churches}

In the Nigerian context, the churches emerging from the second wave of African Initiated Christianity (Spiritual/Indigenous Churches, as outlined in the Introduction to the volume) are commonly known as the Aladura (Praying Churches) or Ijo Elemi (Spiritual Churches). According to Ayegboyin, they are referred to as Aladura because of their intense fervour for energetic prayer. They are called Ijo Elemi (Yoruba) and Ishoshierrhi (Urhobo) because of their emphasis on the spirit while their interest in faith healing and exorcism has earned them the name prophetic and healing ministries (Ayegboyin 2017, 18).

Four churches designated by Ayegboyin as belonging to this group are: the Cherubim and Seraphim Movement (C \& S), the Christ Apostolic Church (CAC), the Church of the Lord (Prayer Fellowship) Worldwide ${ }^{2}$ and the Celestial 
Church of Christ (CCC) (Ayegboyin 2017, 18). All four of these churches started within the South-West zone of Nigeria among the Yoruba-speaking population and are known as Aladura Churches. The term 'Aladura' means 'owner of prayers'. The churches were so named because of the high premium which they placed on prayer, which is one indication of their high level of spirituality. This distinctive form of spirituality which some scholars have aptly referred to as Ijo Elemi 'Aladura spirituality' has in many ways labelled the churches as more aligned with spiritual activities than involvement with social transformation activities (Ayegboyin 2017, 18; Pobee and Ositelu 1988, 27-330). The Aladura Churches rapidly expanded throughout Yorubaland during a revival movement in the 1930s, becoming an important feature of western Nigerian society. Joseph Ayo Babalola (1959), a Yoruba Anglican and public works employee, had a series of visions that brought him to the Precious Stone Society. He went on to become a General Evangelist in the CAC, which would become Nigeria's largest Aladura Church. $\mathrm{He}$ emphasised using 'water of life' (blessed water) in healing rituals. Other important church leaders in that period were Josiah Olunowo Ositelu of Church of the Lord Aladura, Moses Orimolade Tunolase of Cherubim and Seraphim Church and Samuel Bilewu Oshoffa of Celestial Church of Christ.

\section{Aladura Churches as agents of social transformation}

Aladura Churches in Nigeria are known to be Spiritual Churches. It is believed by Africans that Mission Churches created a spiritual vacuum. Mission Churches failed to attend to certain spiritual challenges and needs. Aladura Churches are able to meet them. This can be corroborated in the words of Ayegboyin and Ishola $(1997,29)$ :

In West African nations where there are very few hospitals, and costly medicine is beyond the reach of the majority, one would reasonably expect that the promise of cura divina (divine healing) would attract a number of people. Indeed, sickness is by far the most common reason which people give for attending AICs. Testimonies of healings, soundness and miracles are heard from many about their answered prayers. In quite a number of cases those concerned claim that they first went to the hospitals, and or consulted traditional healers. Then, they resorted to an indigenous church when the foreign physicians and herbalist failed them.

However, Aladura Churches are not only about spirituality. They have contributed immensely to social transformation and human development and continue to do so. Some of these transformation activities are discussed below.

\section{Educational services}

Aladura Churches have improved educational standards in various ways in South-West Nigeria (Oyewole 2004, 22). This is evident in their establishment 
of elementary and secondary schools. Some of the leaders of Aladura Churches have been founders of these schools. For instance, some elementary schools that were founded by Aladura Churches are: Aladura Comprehensive High School, Anthony Lagos, the Church of the Lord Nursery and Primary School, Ogere Remo, Ogun State, Saint John Primary School, Orimolade, Ondo, Orimolade Community Grammar School, Ondo, Cherubim and Seraphim College, Surulere, Lagos; and Celestial Church of Christ High School, Oke Ado, Ibadan, to mention but a few.

Unlike the Pentecostal Churches or the Mission Churches in Nigeria (Adedibu 2018, 5), Aladura churches in Nigeria presently have limited investment in university education. The observable disparity in investment in private tertiary education might be due to a lack of forward planning and financial means. The leading university is Joseph Ayo Babalola University, founded in 2006 by the CAC, in Ikeji-Arakeji, Osun State. The second university is the proposed and almost complete Moses Orimolade University in Omu Aran, Osun State, under the auspices of the Cherubim and Seraphim Church.

However, in the past some of the primary and secondary schools established by Aladura Churches have been taken over by the Nigerian government in SouthWest Nigeria due to financial constraints and lack of manpower (interview Adebayo Kehinde 2017). Apart from this, Aladura Churches in their educational capacity organise extramural classes for candidates preparing for examinations such as the Senior Secondary Certificate Examination and the University and Tertiary Matriculation Examination (interview Israel Akinadewo 2017). This programme is also open to children and wards of members and non-members after registration with a token fee. The churches are responsible for the payment of teachers' salaries, while some members volunteer to teach without remuneration. Some of the Aladura Churches in Nigeria organise other educational training and seminars for church members and non-members. The churches engage in educating their young members by organising seminars on sex education, marriage, and job opportunities, and workshops on security and other themes. Youth empowerment is another social involvement, whereby youths are trained in different crafts such as arts, hair barbing and hairdressing, netting, soap making, shoe making and tailoring (interview Solomon Alao 2017).

Vocational and technological training is one of the ways in which individuals are empowered and become self-reliant in our contemporary society. The import of this development has seen the proliferation of various entrepreneurships through vocational training by many AICs. Some of these ventures are sole proprietorship requiring minimal financial outlay such as interior decoration, soap making, the use of pottery and traditional cloth weaving using contemporary approaches. This training has contributed to economic independence and the survival of traditional African culture through the production of hybrid African attires as well as indigenous cosmetics and jewellery by these mediumscale entrepreneurs.

The uniqueness of the multifaceted interventionist approaches of AICs is evident within the social strata of most of these churches. Participants are 
encouraged to develop various streams of income and be self-employed to contribute to their emancipation from poverty and social vices, which are noted to be a by-product of a lack of gainful employment opportunities, economic dependency on the state and the challenge of moral and fiscal corruption of the ruling class in Africa. The results of this vocational and technological training have in different ways transformed life within and outside the community (Oyewole 2004, 21).

\section{Health services}

The World Health Organization (WHO) defined health in its broader sense in 1948 as a state of complete physical, medical and social well-being and not merely the absence of infirmity (Jakab 2011, 3). Attempts are being made by Aladura Churches to improve people's health in various communities (interview Bisi Ademosun 2017).

My impression on the basis of the field study mentioned above was that some of the health services provided by Aladura Churches have contributed in immense ways to members' and non-members' health status. For instance, women's societies and men's societies of some Aladura Churches organise healthcare services during their annual anniversary. Notable health services organised by a women's society include keep fit exercises, first-child medical advice and medical check-ups while the men's societies consult medical doctors for free eye treatments, blood pressure tests, blood sugar tests, diagnoses, genotype tests, urine tests, HIV/AIDS tests among others. Apart from the payment of hospital bills of the people that need medical assistance, such as those affected by motor accidents, fires, protracted illness, to mention but a few, it is reported that much money is spent on health services every year by the Salem Evangelical Church of Christ (interview Magnus Atilade 2017). Under this scheme, the church pays for the drugs and medical treatment of people needing medical assistance and their progress monitored.

Salem Welfare Outreach of Nigeria, a ministry of Salem Evangelical Church of Christ, has also been proactive in health issues in society. This is carried out by organising free medical services such as health talks lectures on breast cancer and the prescribing of drugs by medical practitioners. The Hospital Visitation Committee of some churches embarks on visiting the sick in the hospital and at home. This visitation is sometimes accompanied by the provision of some basic needs like food items. This committee also encourages blood donation, usually for their fellow members who are in need of blood whenever medical practitioners visit from the hospital. The committee also sees to the payment of hospital bills after the verification of the person in question (interview Abdulralman 2017).

\section{Political activities}

In Nigeria, many people believe that politics is a dirty game and therefore decide not to participate in politics. However, as I have argued elsewhere, if it is 
a dirty game, then people who are clean are needed to clean up the mess (Akindolie 2012, 56). This seems to be what Aladura Churches have been trying to do. Aladura Churches have, over the years, encouraged their members to participate actively in politics. Many church leaders encourage their members to participate in elections (Akindolie 2012, 56). As Bompani observes with reference to the South African context, AICs might be less involved in national political debates than Mission Churches, while being active at a local level (Bompani 2008, 665-677). This resonates with the Nigerian context. For instance, part of the social work of the Church of the Lord (Prayer Fellowship) Worldwide is to participate in elections, monitor and sensitise people by encouraging them to vote and telling them what and what not to do with the help of radio and television adverts, posters and handbills. The church also conducts public political sensitisation programmes for their surrounding communities during local, state and presidential elections. These go a long way in helping to change the political orientation of the members and non-members towards involvement in free and fair elections from the grass roots to the national level (interview Babatunde Gbogboade 2017).

An example of international political involvement is the Church of the Lord (Prayer Fellowship) Worldwide's advocacy on nuclear disarmament. Its Primate, the Most Rev. Dr Rufus Ositelu, is a strong advocate for peace at the international level and has on numerous occasions condemned nuclear weapons. Speaking at the Second Annual Interfaith Meeting commemorating the 71st anniversary of the bombing of Hiroshima and Nagasaki organised by the Peace, Justice and Empowerment Movement in London on Friday 16 September 2016 he said: we believe that using the energy of the atom in ways that threaten and destroy life is a sinful misuse of the fundamental building blocks of God's creation (interview Adebayo Kehinde 2017).

\section{Challenges and prospects}

\section{Insufficient funds}

It is established that one of the major social problems facing almost every organisation in Nigeria is insufficient funding (Akindolie 2012, 94). This is no different for Aladura Churches in Nigeria, since these are self-funding organisations. As a result, it is impossible for the religious bodies to improve upon their social welfare packages, payment of hospital bills, provision of recreation centres and provision of scholarship funds for the indigent. Thus, insufficient funding limits the achievements of the church in its social responsibility. Insufficient funds lead to a cut in the many social transformation aids given to beneficiaries. The provision of many social services is abandoned because of inadequate funds.

Restriction is another implication of inadequate funds. It manifests itself in many cases where conditions are set for the beneficiaries that are seeking assistance mostly among indigent students. In other words, beneficiaries are expected to meet more stringent conditions before they can be financially assisted. This 


\section{Akinwumi Akindolie}

restricts others who might need such assistance as only a few out of many people can be supported. In many cases this screening method is a result of limited resources. The fact remains that, due to the local intensive way of generating funds in the religious bodies in Nigeria, especially in African Initiated Churches, it is evident that the Aladura Churches do find it difficult to embark on large social transformational projects (interview Magnus Atilade 2017).

\section{Shortage of personnel}

It is quite clear that a lack of personnel has seriously reduced the quality of social transformation activities among religious bodies in Nigeria and prevented them from achieving their goals (Akindolie 2012, 96).

Due to the stress inherent in the organisation and administration of social services, it is evident that people find it difficult to participate in the long process of serious verification, counselling, training and monitoring of beneficiaries whenever they apply for social aid. This is underscored by the fact that these activities do not have monetary value attachment. Therefore, with all these shortcomings, people find it inconvenient to join the organisation because they cannot cope with the conditions of attending meetings, close monitoring, visitation, planning and risk taking/management. Moreover, from the field study during this research, it was noted that due to the associated challenges of development in a country like Nigeria as a Third World country, a lack of technical know-how in terms of management, administration and project management exists in comparison to the developed world. The multiplier effect of this development might be responsible for the inadequacies in various social service initiatives of AICs. Information gathered from the field studies showed that many of the personnel were not always available to diligently discharge their duties for the progress of these social services. However, this may be connected with the volunteer nature of the Aladura Churches' social transformational services (Akindolie 2012, 99).

\section{Conclusion}

From the above, it is evident that, Aladura Churches have contributed and are still actively contributing to social transformation in the areas of education, politics and health services to members and non-members. Therefore, Aladura Churches are not only about spirituality, as tagged by some scholars in the existing literature. Despite the challenges faced by the religious organisations in terms of insufficient funds and shortage of personnel due to the fact that the churches were said to have been almost exclusively patronised by the poor, the illiterate and the sick at its inception, these days we find among the members persons occupying social and economic positions in society. Among them are engineers, lawyers, senior police and army officers, professors, medical personnel and business tycoons. Thus, this positive change has enhanced the various innovations initiated by the Aladura Churches in their social transformation 
activities being carried out in different ways. Therefore, as much as the Aladura Churches will continue in their provision of social services by tailoring their operations to meet the social needs as well as the spiritual needs of society, there is still the prospect of further growth and development of the Aladura Churches in Nigeria and Africa as a whole.

\section{Notes}

1 The research project was awarded to Humboldt University Berlin by the German Federal Ministry of Economic Cooperation and Development. The author of this chapter took part in the Nigeria field study as a junior researcher.

2 Previously called the Church of the Lord (Aladura).

\section{References}

Adedibu, Babatunde A. 2018. 'The Changing Faces of African Independent Churches as Development Actors across Borders.' HTS Teologiese Studies/Theological Studies 74 (1). https://doi.org/10.4102/hts.v74i1.4740.

Adeoba, A. O. 2012. Religious Organization and Social Transformation. Dynamic Publishers, Lagos.

Akindolie, Akinwumi Ambrose. 2012. 'Religious Organisation as Tools for Social Transformation of University of Ibadan Community.' Master's thesis, Department of Religious Studies, University of Ibadan, Nigeria.

Ayegboyin, Deji Isaac. 2017. 'Taxonomy and Revolution in African Christianity: The Nigerian Experience.' Inaugural lecture for the 2016/2017 academic session, 9 November, 2017, University of Ibadan.

Ayegboyin Deji Isaac, and S. Ademola Ishola. 1997. African Indigenous Churches: An Historical Perspective. Lagos: Greater Height Publications.

Bompani, Barbara. 2008. 'African Independent Churches in Post-Apartheid South Africa: New political interpretations.' Journal of Southern African Studies 34, no. 3: 665-677. http://dx.doi.org/10.1080/03057070802259928.

Borowik, Irena. 2002. 'The Roman Catholic Church in the Process of Democratic Transformation: The Case of Poland.' Social Compass 49, no. 2: 239-252.

Bourdillon M. F. C. 1991. 'Religion, Medicine and Healing.' In Religion and Society in Nigeria. Historical and Sociological Perspectives, edited by Jacob K. Olupona, and Toyin Falola, 146. Ibadan: Spectrum Books.

Dzurgba, Akpenpuun. 1991. An Introduction to Sociology of Religion. 2nd edn. Ibadan: Centre for External Studies, University of Ibadan.

Familusi, Olumuyiwa Olusesan. 2010. 'Religious Politics and Its Implication for Sustainable Development in the Post Independence Nigeria.' In Journal of Sustainable Development in Africa 12, no. 5: 158-600.

Familusi, Olumuyiwa Olusesan and Oke, Olusegun P. 2011. 'A Christian Dimension to Poverty Discourse in Nigeria.' Orita: Ibadan Journal of Religious Studies 43, no. 2: 75-94.

Jakab, Zsuzsanna. 2011. 'Health 2020: A New Policy for a New Era.' Presentation held at the 14th European Health Forum Gastein at Bad Hofgastein, Austria, 6 October 2011. www. euro.who.int/_data/assets/pdf_file/0003/152175/RD_Gastein_pres_06Oct.pdf?ua=1.

Johnstone, Ronald L. 2001. Religion in Society. Upper Saddle River, NJ: Nancy Roberts.

Haralambos, Michael, Martin Holborn, and Robin Heald. 2008. Sociology Themes and Perspectives. 7th edn. London: Harper Collins. 


\section{Akinwumi Akindolie}

Nabofa, M. Y. 1988. General Introduction to the Study of Religion. Ibadan: Department of Adult Education, University of Ibadan.

Nigerian Baptist Convention. 2009. 'Kingdom Expansion: Our Coast through Social Ministry.' In Annual Convention Handbook 96: 6-11.

Öhlmann, Philipp, Marie-Luise Frost, and Wilhelm Gräb. 2016. 'African Initiated Churches' Potential as Development Actors.' HTS Teologiese Studies/Theological Studies 72, no. 4. https://doi.org/10.4102/hts.v72i4.3825.

Oguntoyinbo-Atere, M. I. 2005. 'The Redeemed Christian Church of God Programme for the Poor in the Context of Lucan Teaching.' Ph.D. thesis, Department of Religious Studies, University of Ibadan, Nigeria.

Ositelu, Gideon Adebandele. 2010. Christianity in West Africa up to 1914. Ibadan: Hope Publishers.

Oyewole, Yahya. 2004. 'Religious Organizations and Progressive Social Change: A Case Study of Ansar-ud-Deen Society of Nigeria.' Islamic Studies 43, no. 4: 631-651.

Pobee, John S., and Gabriel Ositelu. 1988. African Initiatives in Christianity: The Growth, Gifts and Diversities of Indigenous African Churches: A Challenge to the Ecumenical Movement. Geneva: WCC.

Scharf, Betty R. 1970. The Sociological Study of Religion. London: Hutchinson and Company.

Tachin, P. 2019. 'The Nigerian Church in Its Social Context in African Christianity in Local and Global Contexts.' In A Festschrift in Honour of Rev. Professor Isaac Deji Ayegboyin at 70, edited by S. A. Fatokun, J. K. Ayantayo, O. O. Familusi, S. M. Mepaiyeda, and S. O. Okanlawon, 393.

\section{List of interviews}

Abdulralman. 2017. Prophet Salem Evangelical Church of Christ Ikorodu Road, Ilupeju, Lagos.

Adebayo Anthony Kehinde. 2017. Deacon Ecumenical Officer, Church of the Lord Aladura in Ogere, Ogun State.

Akinadewo Israel. 2017. Baba Aladura, Mutailatu Church Worldwide, Mayfair Ajah, Lagos.

Alao Solomon. 2017. Most Elder Apostle Dr Church Leader of the Sacred C\&S Church Holy Mountain of Salvation, Aguda Surulere, Lagos.

Bisi Ademosun. 2017. Baba Aladura, Prophet, Mount Jieawowrrar All Saint Church of Christ Aladura Worldwide, Odogbolu, Ogun State.

Emmanuel Gbogboade. 2017. Bishop, Principal Aladura Theological Institute and the Bishop of Ogere Diocese, Church of the Lord Aladura in Ogere.

Magnus Atilade. 2017. Archbishop Prof. Leader of Gospel Baptist Conference of Nigeria. 